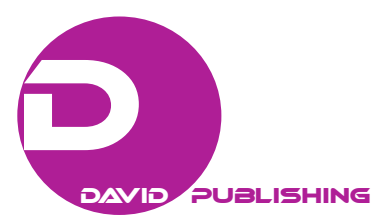

\title{
Principal Features of Building Social Accounts Matrix and Improving Statistical Database for Eco-countries
}

\author{
Vilayat Valiyev, Malik Mehdiyev, Arzu Suleymanov, Elnur Alakbarov, Rauf Musayev \\ Institute for Scientific Research on Economic Reforms (ISRER), Baku, Azerbaijan \\ Elvira Nagoibaeva \\ Kyrgyz Economic University, Bishkek, Kyrgyzstan \\ Natalya Zakharova \\ National Statistical Committee, Bishkek, Kyrgyzstan
}

\begin{abstract}
With common borders of the population, total area, and GDP (PPP-based) of Economic Cooperation Organization (ECO) member states are estimated as 416 million persons, 7.9 million $\mathrm{m}^{2}$, and US\$2.7 trillion respectively (2010 data). Although heterogeneous in the extent, there is economic development, overall, with serious energy and transport-transit relations among countries that is reflected in growing trade turnover year-by-year. However, there are still rather unused resources and capacity in such areas of cooperation among countries as exchange of energy, transport services, agricultural and industrial goods, use of opportunities for tourism, promoting investment and innovation processes and other areas. Certainly, maximum and optimal use of these resources calls for availability of analytical means capable of accounting for relations both within member states and among them. The implementation of computable general equilibrium (CGE) modeling in each member state would thus be of great significance in resolution of these problems both in terms of accounting for input-output linkages within the countries as well as enabling impact of main trading partners and goods and services among countries. The analysis carried out indicates that there are a number of problems in application of CGE model in most of the member states. As such, input-output tables are not compiled in some countries, while in others despite the fact that these tables are compiled, there are no attempts to build the model, yet in other countries, even if the CGE model is implemented, there are difficulties in taking into account the real results in the face of serious problems related to improving national accounts system database. Summarizing these problems, it is possible to conclude that to ensure the application of a CGE model,
\end{abstract}

Vilayat Valiyev, Ph.D., professor, director of Institute for Scientific Research on Economic Reforms (ISRER), Ministry of Economy and Industry of the Republic of Azerbaijan, Baku, Azerbaijan.

Malik Mehdiyev, senior research worker of Institute for Scientific Research on Economic Reforms (ISRER), Baku, Azerbaijan. Arzu Suleymanov, head of department at Economic modeling and analysis of Institute for Scientific Research on Economic Reforms (ISRER), Baku, Azerbaijan.

Elnur Alakbarov, research worker at Economic modeling and analysis of Institute for Scientific Research on Economic Reforms (ISRER), Baku, Azerbaijan.

Rauf Musayev, senior specialist at Economic modeling and analysis of Institute for Scientific Research on Economic Reforms (ISRER), Baku, Azerbaijan.

Elvira Nagoibaeva, Ph.D., head of department of Accounting, Analysis and Audit of Kyrgyz Economic University, Bishkek, Kyrgyzstan.

Natalya Zakharovạ, senior specialist at National Accounts Department, National Accounts National Statistical Committee of Kyrgyz Republic, Bishkek, Kyrgyzstan.

Correspondence concerning this article should be addressed to Elnur Alakbarov, AZ 1011, 88a H.Zardabi ave. Baku, Azerbaijan. E-mail: alekberov.elnur@gmail.com. 
there is a great need to work out procedures of compilation of a social accounts matrix (SAM) that lies on the basis of this model, for which the relevant statistics of a member state must be improved. Considering the above-mentioned, the presented research, makes procedures and proposals on compilation of SAM, improves statistical data for researching the extent of application of CGE Model in ECO member states, and identifies the degree of availability and organization of relevant data to develop input-output tables and respective SAM.

Keywords: social accounts matrix (SAM), system of national accounts (SNA), input-output table, CGE model, ECO countries

\section{Introduction}

It is the contemporaneous practice in statistics that the vast majority of world countries make use of, with a number of reports and additional balance sheet tables to describe and analyze macrostatistical models of their respective economies. By constructing macrostatistical model of the economy, countries strive to see formation, development, and future prospects of important economic interactions occurring in the four phases of broad reproduction (namely production, distribution, exchange, and consumption). In the meantime, macrostatistical models are of great importance in building economic and mathematical models enabling various estimations.

Macrostatistical model is built through a system of national accounts (SNA). Emergence and successful implementation of SNA is a kind of result of historical evolution of economics science. The first ever application of macrostatistical model in the economy took place in the 17th century. As such, English economists estimated national income of France and England first time ever in the history, and then used this estimation to study the impact of change in the tax system on the economy of the country. In 1758, Kene, on the other hand, summarized statsitical materials on French economy and developed a model of national economy in the form of "Economic tables" (or Kene's zig-zagz). There is no doubt that Kene's economic table was a primary form of current SNA.

First macrostatistical models were created in 1923-1930s in the Union of Soviet Socialist Republics (USSR). In early 30s, Soviet economist Pervukhin (Chairman of State Planning Committee of the Soviet Union) first proposed the idea of studying national income in three phases of of economic turnover (production, distribution, and use) in his Remarks to National Economy's Balance Sheets of 1928-1930s. At that stage, key features and ratios of current input-output balance had commenced to emerge in the balance sheets of the national economy. Generally speaking, the idea of the current input-output balance was a product of discussions held during the period of new economic policy (NEP) of the Soviet Power, which was then given by Leontief (1990) as serious mathematical equations reflecting interactions among sectors of economy, including gross output, intermediate consumption, and final consumption. It is noteworthy that theoretical explanation of such economic terms as value added and intermediate consumption were introduced by Smith (1955) and Marx (1969) respectively.

It must be noted that the idea of input-output balance was first proposed by Dimitriev (1974) and was eventually used in compilation of the first ever national economy's balance sheet.

After the Second World War, national economy's balance sheet had a great impact on the development of SNA with input-output balance truning into an integral part of SNA.

Theoretical foundations of the SNA also include the theory on factors of production (labour, land, capital and entrepreneurial skills). According to this theory, factors involved in the production of national product and 
national income must be paid their "dues". The broad reproduction concept considers all income-generating types of activity, except for illegal and household activities as productive. There are two reasons for such exception: The first one is related to acquiring information and the second reason is due to uncertainty of outcomes of such activity types.

In 1925, Marshall proposed the concept of annual net national income (a total of goods and services including income from foreign investments and excluding goods and services produced and depreciation) in his book Principles of Economics, which became a basis for calculation of the SNA indicators. Consequently, economist distinguished concepts of national product and national income, and provided a rationale for estimating these concepts at market prices accountng for inflationary processes rather than based on factor costs. The UN's SNA of 1993 takes the concept proposed by an English economist Hicks (1939) in his book Value and Capital as a theoretical foundation of all indicators. According to this concept, total level of income produced in a specific period has to be taken at such a maximum level that would be sufficient to be spent on consumption without using the initial amount of capital. Specification of Hicks' income concept (1939) for application in macrostatistical analysis led to creation and classification of unified system of SNA definitions. This in turn gave rise to elaboration of of such important indicators as gross domestic product, initial income stock, disposable income, savings etc., and defined interactions at the basis of system of accounts as a macrostatistical model of economic turnover.

SNA's theoretical foundation is also based on Keynes' government regulation theory (1936). Principles of organizing information necessary for description and analysis of macroeconomic system are provided in his book General Theory of Employment, Interest and Money. He developed a system of macroeconomic indicators (gross income, consumption, investment, savings) related to decisionmaking and policy formulation on market regulation, and proved that government regulatory agencies may influence input parameters of the system to get the desired changes in the output variables of the system.

A new era commenced in the development of macrostatistical model of the economy after the Second World War. It was related to harmonization of different national systems and systemization of international comparisons of macroeconomic indicators and their components. This process was founded on the SNA principles accounting for real possibility of obtaining data in 1951 developed by Stone, Keynes' student and successor. Under his leadership, the SNA standard of the UN was first developed in 1953 and the second standard "a blue book" was issued in 1968. Along with calculation of national product and national income, these standards also reflected the macroeconomic indicators of assets and inter-sectoral interactions. Many countries altered their statistics practices based on recommendations of the blue book.

The UN shifted to a new SNA standard in 1993 due to international harmonization.

As a result of globalization impact though, the UN adopted a new methodology for SNA in 2008 (Retrieved from http://unstats.un.org/unsd/nationalaccount/docs/SNA2008.pdf).

The modern SNA integrates a homomorphious macrostatistical model that enables assessment of both general outcomes of economic development as well as economic interactions. The calculation of SNA indicators has taken an important analytical meaning and is almost a functional method of state of health diagnostics of alive economic organism.

Hence, as key information source of compilation of SAM, SNA calculations are also successfully used in selection of government's economic policy scenarios, in short- and medium-term forecasting, in country 
economic comparisons, and in international economic relations.

Looking at evolution of a macro statistic descriptive history of economy, it is revealed that SNA is the main macro statistical model today incorporating all accomplishments of history of economic thought, starting from François Kennan's tables resembling the characteristics of early elements for practical use, through Karl Marx' model of extended reproduction model, and including even a modern cross-sector balance of distribution of goods and services. SNA is a set of standard recommendations agreed internationally, relying on economic theory in calculation of economic indicators. Theoretical foundation of SNA allows to compile economic indicators in such a way that enables both economic analysis and making policy decisions. It ensures that a detailed report can be prepared on complicated economic activity and interaction among economic agents and group of agents.

As a macro statistical model, the SNA is an important information basis in setting up favorable projection means based on identifying reciprocal effects in the economy. It is this database that served as a basis on which it was possible to construct such instruments of empirical economic analysis as an input-output model and a general equilibrium model. The most suitable presentation of SNA for analytical purposes is the matrix of accounts for analysis of social processes (MAASP), which in short is referred to as SAM.

\section{Importance of Constructing SAM for ECO-countries}

Compilation, analysis, and use of SAM in setting up projection tools allows to penetrate into all sophisticated economic processes while regulating such processes from the perspective of principles of economics. Such a great analytical capacity can play a great role not only in terms of governing problems of economic regulation within one country, but also managing inter-country economic cooperation issues at a level of a number of countries. Particularly, here a measurement of mutual benefits from results of reciprocal trade and investment becomes a central issue. In this context, it is important for countries of ECO to compile SAM and coordinate these matrices.

\section{Challenges}

Despite all ECO member states have SAMs, it is not used much effectively as an analytical tool. In other words, although there are sufficient opportunities to create an analytical tool, it remains to be created. However, such analytical tools have been created in the example of other countries and are being used successfully. Using such tools in ECO countries might play a great role in defining areas of cooperation and raising efficiency of mutual benefits. Key challenges in compilation of SAM in ECO member states are as follows:

1. Lack of methodology to put SAM in the format of the MAASP.

2. Wrong perceptions about light and full versions of MAASP, or even input-output balance and MAASP being identical. Light version of MAASP can only be compiled based on input-output balance and SAM.

3. Lack of data to develop full version of MAASP. Detailed information are required to disaggregate SAM data, such as aggregate tax data broken down by sectors of economy and types of taxes, exports and imports data broken down by sectors of economy and trading partners. Same can be said about incomes, investments, transfers, and so on.

4. Difficulties arising from methodological differences in compilation of data on accounting, statistical, and taxation recording. Statistical data on activity of economic agents are formed based on accounting data. It is done using an accrual method. Taxation data can be applied in parallel using a cash method, which would 
cause differences in tax base by sectors. Statistics agency defines the entire tax base through accrual method. Since breakdown of taxes by sectors and types of taxes is not available at the statistics agency, SAM reflects only aggregate data in this regard, while there are no such data by types of taxes. However, compiling these data based on tax agency's data the balance of data is violated.

5. Variety of tax and subsidy types also which complicates the application to either production or products. Since MAASP is comprised of set of balances as an explicit practical tool, it is required that each economic indicator is placed on a specific cell. However, SAM does not enable such breakdown of taxes by products and production. Each country's economy, on the other hand, has specific taxes and subsidies.

6. Lack of specialists capable of working on SAM as a result of no seminars and courses held on compilation of MAASP internationally.

\section{Methodology}

Compilation of SAM is to be implemented in a strictly structured manner, as data used to develop the matrix must be systemic, accurate, well-grounded, reflecting reality adequately, and acceptable to everyone. Compiling such data is based on a number of normative-legal acts. Such normative acts are developed and published by United Nations Statistics Bureau, Organization of Economic Cooperation and Development, International Monetary Fund, Food and Agriculture Organization of the United Nations. Key data to be used in the compilation of SAM are the following:

(1) Table on stock of goods and services in the economy to be used in compiling SAM;

(2) Table on use of goods and services in the economy at consumer prices to be used in compiling SAM;

(3) Table on trade, intermediation, and transport charges to be used in compiling SAM;

(4) Table on net taxes on products to be used in compiling SAM (United Nations, 1999). This table should also be complemented by the following additional information:

(a) On taxes and subsidies on products:

- Value added tax by sectors;

- Other taxes on income from sales of goods (works and services) by sectors;

- Excises by sectors;

- Taxes and levies on various activities by sectors (taxes on lottery games, levy collected from suppliers, allocations from income of various service providers, a single trade tax);

- Customs collections, customs duty on imports by sectors;

- Customs duty on exports by sectors;

- Subsidies to government organizations by sectors;

- Subsidies to cover losses of organizations by sectors;

- Other subsidies by sectors.

(b) ON taxes and subsidies on production:

- Property tax by sectors;

- Land tax by sectors;

- Road tax by sectors;

- Collections for use of roads of Azerbaijan by sectors;

- Mining tax by sectors;

- Subsidies by sectors. 
(5) Input-output balance at basic prices to be used in compiling SAM;

(6) Indicators of SNA of the Republic Azerbaijan to be used in compiling SAM:

- Aggregate accounts by institutional sectors at current prices;

- Cross-classification of total output, intermediate production, and value added by types of economic activity and institutional sectors.

Above-mentioned data are to be placed in the table of 2008 SAM with the following format:

This format is a short version of SAM, which can be infinitely disaggregated depending on the objective of the research.

Table 1

Basic Table of Social Accounts Matrix

\begin{tabular}{|c|c|c|c|c|c|c|c|c|c|c|}
\hline & \multicolumn{6}{|c|}{ Outlays } & \multirow{4}{*}{ Total } \\
\hline & & & & \multicolumn{5}{|c|}{ Our economy } & \multirow{3}{*}{ Rest of the world } & \\
\hline & & & & \multicolumn{2}{|c|}{ Firms } & \multicolumn{3}{|c|}{ Production } & & \\
\hline & & & & Current & Capital & Factors & Products & Activities & & \\
\hline \multirow{6}{*}{ 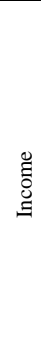 } & \multirow{5}{*}{ 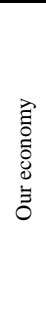 } & \multirow{2}{*}{$\stackrel{0}{E}$} & Current & current transfers & & factor incomes & taxes on product & taxes on activities & $\begin{array}{l}\text { current transfers } \\
\text { from abroad }\end{array}$ & $\begin{array}{l}\text { current disposable } \\
\text { income }\end{array}$ \\
\hline & & & Capital & savings & capital transfers & & & & $\begin{array}{l}\text { capital transfers } \\
\text { from abroad }\end{array}$ & available of funds \\
\hline & & \multirow{3}{*}{ 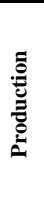 } & Factors & & & & & $\begin{array}{l}\text { payments for factor } \\
\text { services }\end{array}$ & $\begin{array}{|lr|}\begin{array}{l}\text { Factor } \\
\text { received }\end{array} & \text { incomes } \\
\text { abroad } & \text { from } \\
\end{array}$ & factorincomes \\
\hline & & & Products & $\begin{array}{l}\text { Consumption } \\
\text { expenditure }\end{array}$ & $\begin{array}{l}\text { Investment } \\
\text { expenditure }\end{array}$ & & & $\begin{array}{l}\text { demand for } \\
\text { intermediate } \\
\text { products }\end{array}$ & export & $\begin{array}{l}\text { demand for } \\
\text { product }\end{array}$ \\
\hline & & & Activities & & & & sales of products & & & revenue \\
\hline & \multicolumn{3}{|c|}{ Rest of the world } & $\begin{array}{l}\text { current transfers to } \\
\text { abroad }\end{array}$ & $\begin{array}{l}\text { capital transfers to } \\
\text { abroad }\end{array}$ & $\begin{array}{l}\text { factorincomes paid } \\
\text { to abroad }\end{array}$ & import & & & $\begin{array}{l}\text { use of foreign } \\
\text { exchange }\end{array}$ \\
\hline \multicolumn{4}{|c|}{ Total } & use of income & use of funds & $\begin{array}{l}\text { allocation of factor } \\
\text { incomes }\end{array}$ & supply of products & allocation of revenue & $\begin{array}{l}\text { Available foreign } \\
\text { exchange }\end{array}$ & \\
\hline
\end{tabular}

Source: United Nations (2002).

\section{Problems in Statistical Database of ECO Member States in Relation With Compilation of SAM}

There is SAM in all ECO member states. However, input-output balance that is an integral part of SAM is not updated in some countries for each year. These balances are updated for each year in Kazakhstan and Kyrgyzstan. In Azerbaijan, this balance was last compiled in 2006, but has not been updated since then.

Each of the difficulties mentioned above can be found in Azerbaijan, Kazakhstan, and Kyrgyzstan.

\section{Conclusions}

Taking into account the above-mentioned, the following important conclusions can be drawn:

(1) A detailed compilation of MAASP allows to present broad presentation of economy through macroeconomic indicators in a single table-board, which enables to see explicitly a role and significance of each macroeconomic indicator in the entire system of economic indicators. In short, with all its proportions, the economy can be described in numbers;

(2) Based on MAASP, the SAM indicators can practically be made fully ready for setting up analytical tools. In other words all resources and uses can be represented as a set of balances taking into account inter-sector flows and both types of economic activities and economic sectors. Based on SNA, MAASP for republic of Azerbaijan, Kazakhstan, and Kyrgyzstan has been compiled (Appendix 1, 2, and 3); 
(3) Compilation of MAASP has become a necessity analytically giving rise to a need for developing a serious methodology for its compilation;

(4) Detailed compilation of MAASP opens up the following opportunities in learning about and projecting reciprocal impacts in the economy;

- Developing reciprocal impact assessment models for the economy based on SAM multipliers. Based on MAASP, such models for republic of Azerbaijan, Kazakhstan and Kyrgyzstan have been built. As a result of 10\% increase in exogenous demand in agriculture, the results of increase in aggregate demand are shown in tables for all three models(Appendix 4, 5, and 6) (Breisinger, Thomas, \& Thurlow, 2009);

- Developing computable general equilibrium model.

(5) Finally, analytical tools developed based on MAASP allows to study an impact of any group of macroeconomic indicators on all remaining economic indicators, taking into account all reciprocal impacts in the economy.

\section{References}

Breisinger, C., Thomas, M., \& Thurlow, J. (2009). Social accounting matrices and multiplier analysis: An introduction with exercises. Washington, D.C.: International Food Policy Research Institute.

Dimitriev, V. K. (1974). Economic essays on value, competition and utility. Cambridge: Cambridge University Press.

European Communities., International Monetary Fund., Organisation for Economic Co-operation and Development., United Nations., \& World Bank. (2009). System of national accounts. Retrieved from http://unstats.un.org/unsd/nationalaccount/docs/SNA2008.pdf

Hicks, J.R. (1939).Value and Capital:An Inquiry into Some Fundamental Principles of Economic Theory. Oxford: Clarendon Press

Kene, F. (1758). Anthology of economic thought (Translate from French, Moscow, 2008)

Keynes, J.M. (1936). General Theory of Employment Interest and Money (Economic library scanned and edited by AXL_FOX Dekhtyar Gennady, RSU).

Leontief, W. (1990). Essays in economics (Translate to Russian, Moscow, 1990).

Marshall, A. (1925). Principles of economy. Retrieved from http://www.econlib.org/library/Marshall/marP43.html

Marx, K. (1969). Capital (part 1, 2 ed.). Baku: Azerbaijan State Publishing House.

Smith, M. N. (1955). The works of D.Ricardo (Part 1, Moscow, Translation edited by a member of the USSR Academy of Sciences).

United Nations. (1999). Handbook of national accounting-Input-Output table compilation and analysis (Series F, No. 74, New York).

United Nations. (2002 ).Use of macro accounts in policy analysis (Series F, No. 74, New York). 
Appendix 1

Social Accounts Matrix of Azerbaijan

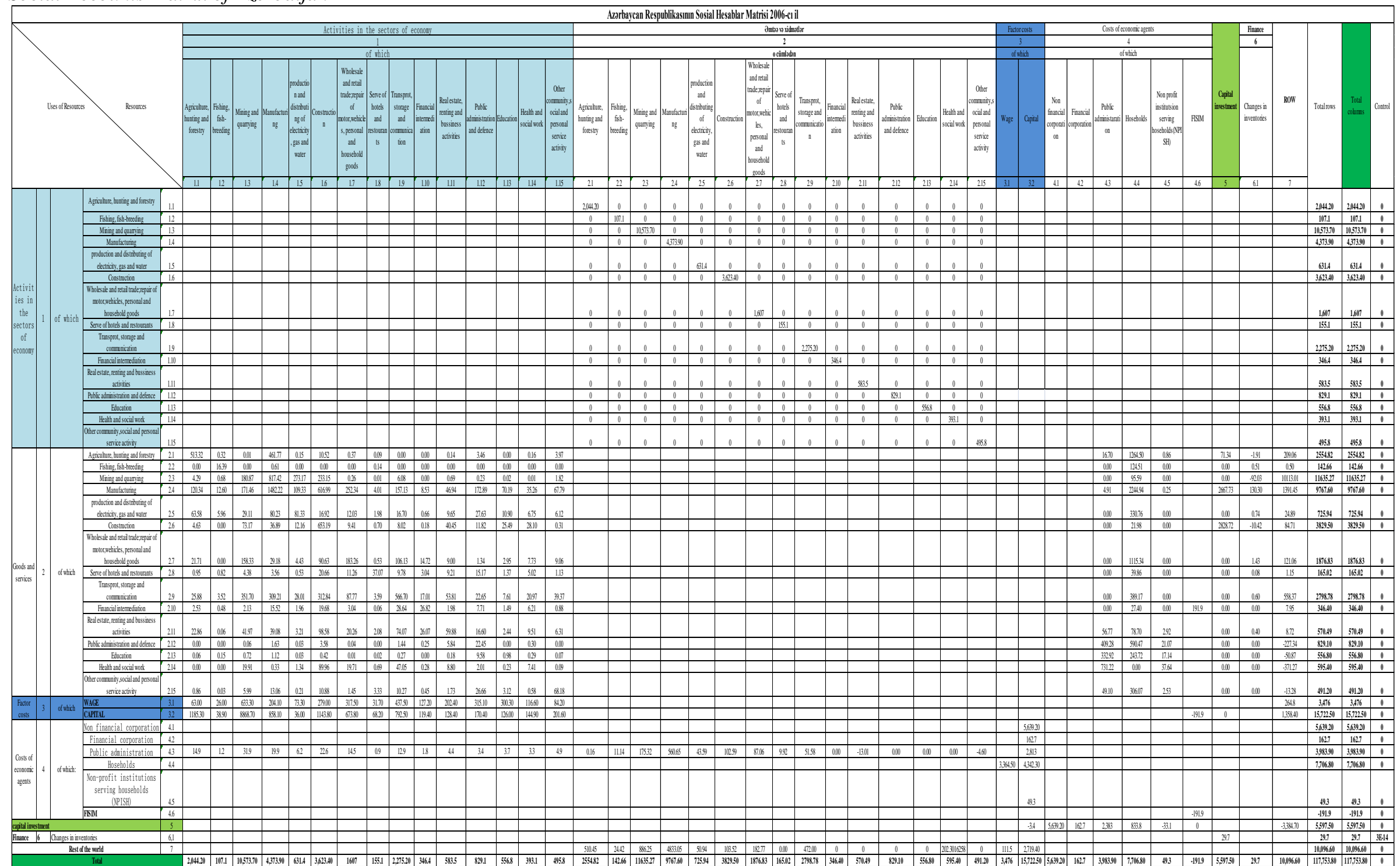


Appendix 2

Social Accounts Matrix of Kyrgyzstan

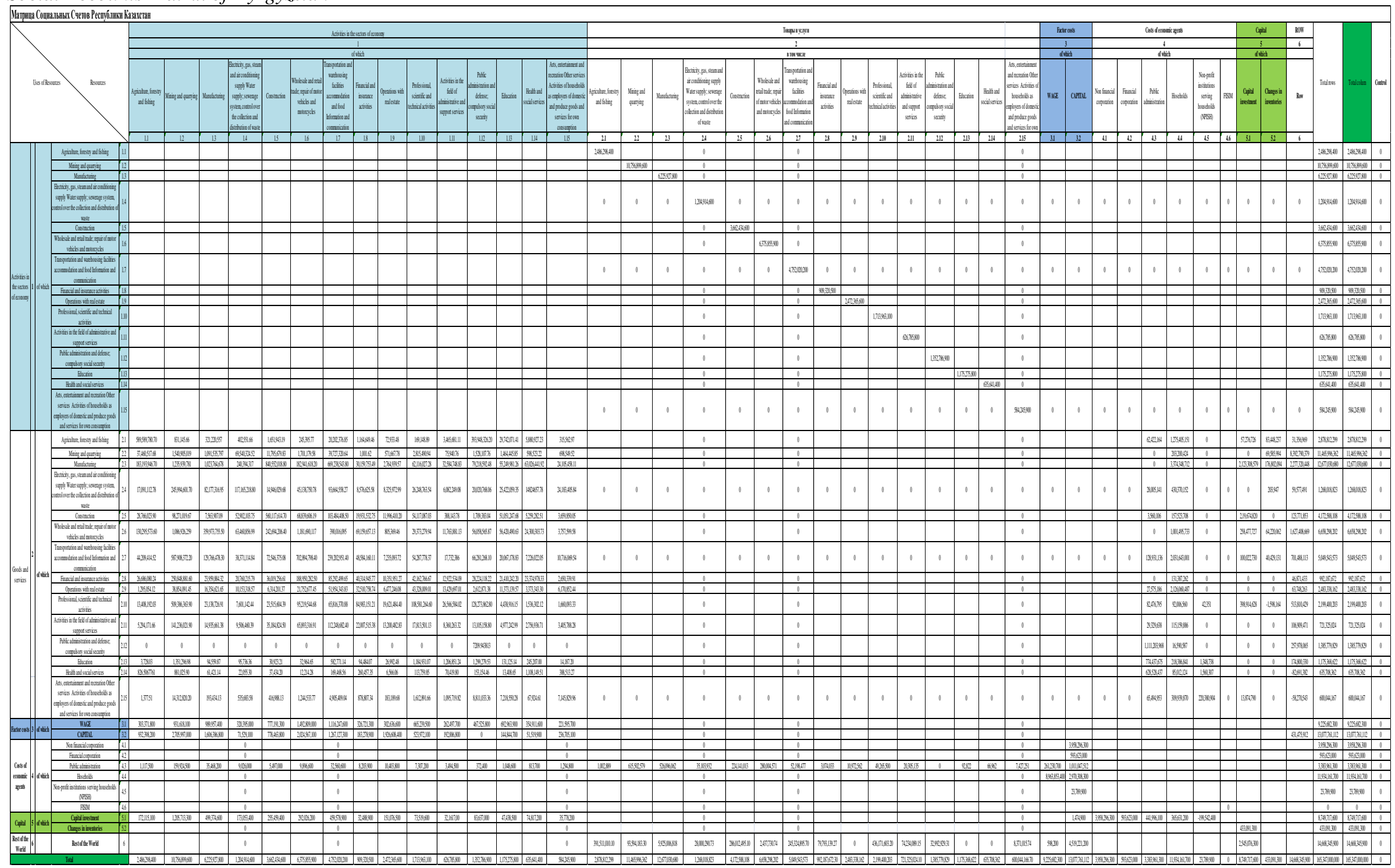


Appendix 3

Social Accounts Matrix of Kazakhstan

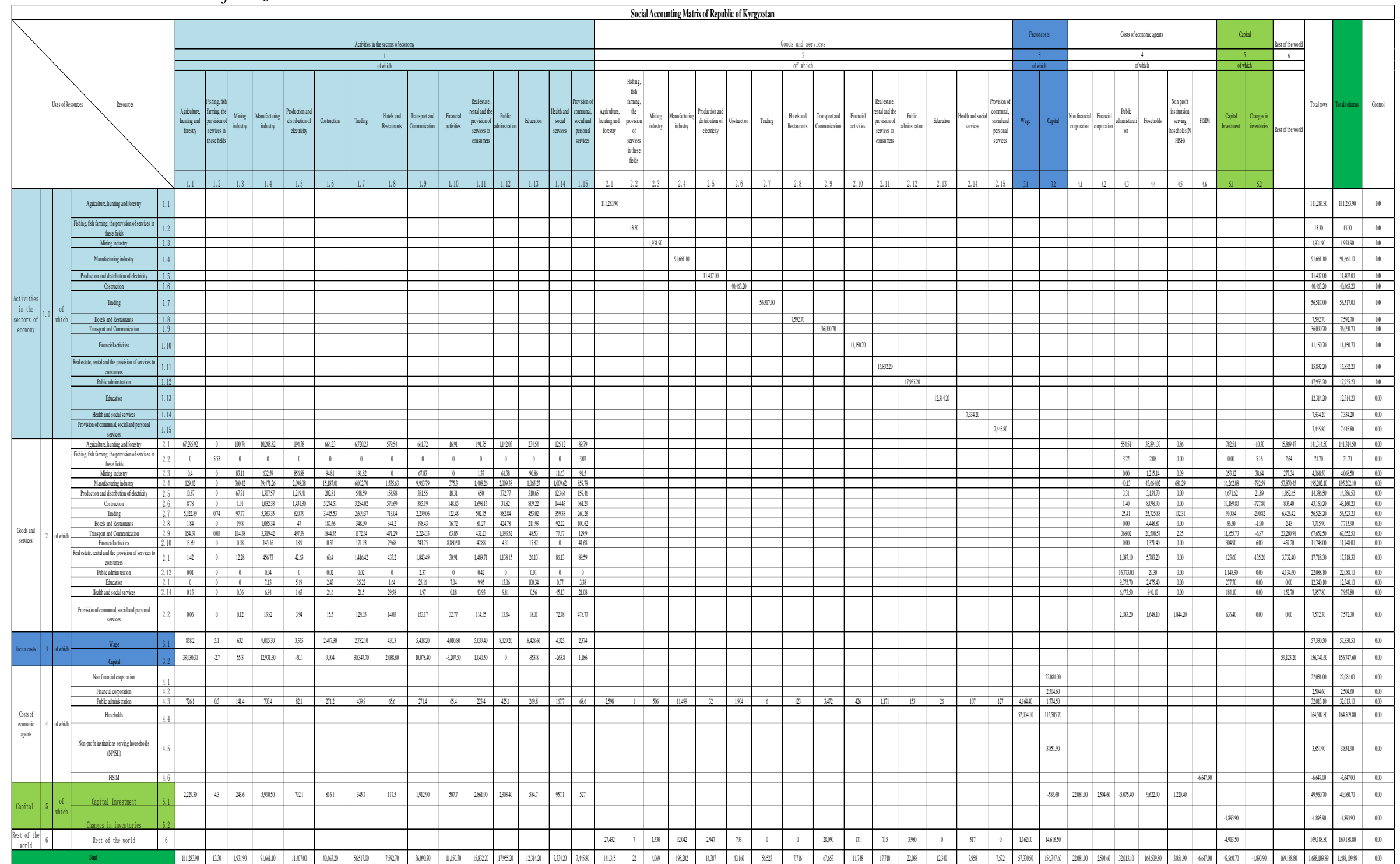




\section{Appendix 4}

Calculation of general multiplier based on the Social Accounts Matrix of Azerbaijan

Calculation of general multiplier based on the Social Accounts Matrix of Kyrgyzstan (mln som)

\begin{tabular}{|c|c|c|c|c|c|c|c|c|c|c|c|c|c|c|c|c|c|c|c|c|c|c|c|}
\hline & \multicolumn{15}{|c|}{ Activities } & \multicolumn{2}{|c|}{ SAM multiplier model } & \multicolumn{5}{|c|}{ Simulation } \\
\hline & & $\begin{array}{c}\text { Agriculture, } \\
\text { hunting and } \\
\text { forestry }\end{array}$ & $\begin{array}{c}\text { Fishing, fish } \\
\text { farming, the } \\
\text { provision of } \\
\text { services in } \\
\text { these fields }\end{array}$ & $\begin{array}{l}\text { Mining } \\
\text { industry }\end{array}$ & $\begin{array}{c}\text { Manufact } \\
\text { uring } \\
\text { industry }\end{array}$ & $\mid \begin{array}{c}\text { Productio } \\
\mathrm{n} \text { and } \\
\text { distributio } \\
\mathrm{n} \text { of } \\
\text { electricity }\end{array}$ & $\begin{array}{c}\text { Costructi } \\
\text { on }\end{array}$ & Trading & $\begin{array}{c}\text { Hotels and } \\
\text { Restaurant } \\
\mathrm{s}\end{array}$ & $\begin{array}{c}\text { Transport } \\
\text { and } \\
\text { Communi } \\
\text { cation }\end{array}$ & $\begin{array}{l}\text { Financial } \\
\text { activities }\end{array}$ & \begin{tabular}{|c} 
Real \\
estate, \\
rental and \\
the \\
provision \\
of services \\
to
\end{tabular} & $\begin{array}{c}\text { Public } \\
\text { adminstra } \\
\text { tion }\end{array}$ & Education & \begin{tabular}{|c} 
Health \\
and \\
social \\
services
\end{tabular} & $\begin{array}{c}\text { Provision } \\
\text { of } \\
\text { communal, } \\
\text { social and } \\
\text { personal } \\
\text { services }\end{array}$ & \begin{tabular}{|c} 
E \\
exogenous \\
demand \\
vector
\end{tabular} & \begin{tabular}{|c}
$\mathrm{Z}$ \\
aggregate \\
demand \\
vector
\end{tabular} & $\begin{array}{l}\text { Change in } \\
\mathrm{E} \%\end{array}$ & 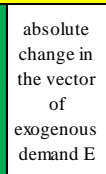 & $\begin{array}{c}\text { Result of the } \\
\text { change in } \\
\text { the vector of } \\
\text { aggregate } \\
\text { demand }\end{array}$ & $\begin{array}{c}\text { Absolute } \\
\text { result Z }\end{array}$ & $\mid \begin{array}{c}\text { Relativ } \\
\text { e result } \\
\mathrm{Z} \%\end{array}$ \\
\hline \multirow{12}{*}{1} & \begin{tabular}{|c|}
$\begin{array}{c}\text { Agriculture, hunting } \\
\text { and forestry }\end{array}$ \\
\end{tabular} & 2.44 & 0.43 & 0.38 & 0.38 & 0.55 & 0.62 & 0.98 & 0.82 & 0.39 & 0.61 & 0.70 & 0.71 & 0.83 & 0.75 & 0.76 & \begin{tabular}{|l|}
$17,197.06$ \\
\end{tabular} & $141,314.50$ & 1.10 & $18,916.76$ & $145,504.42$ & $4,189.92$ & 2.96 \\
\hline & \begin{tabular}{|c|} 
Fishing, fish farming, \\
the provision of \\
services in these fields
\end{tabular} & 0 & 34 & 0.00 & 0.00 & 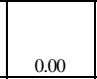 & 0 & 0.00 & 0.00 & 0.00 & 0.00 & 0 & 0.00 & 0 & 0 & 0.00 & .01 & 21.70 & 1.00 & .01 & 74 & 04 & 1.18 \\
\hline & $\begin{array}{l}\text { Manufacturing } \\
\text { industry }\end{array}$ & 0.46 & 0.37 & 0.40 & 1.49 & 0.69 & 0.98 & 0.81 & 0.88 & 0.50 & 0.71 & 0.75 & 0.66 & 0.83 & 0.79 & 0.85 & $70,062.16$ & 195,202.10 & 1.00 & $70,062.16$ & 195,989.37 & 787.27 & 0.40 \\
\hline & $\begin{array}{c}\text { Production and } \\
\text { distribution of }\end{array}$ & 0.03 & 0.03 & 0.04 & 0.03 & 1.13 & 4 & 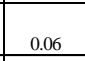 & 07 & 0.03 & 25 & 0.09 & 0.06 & 0.08 & 0.06 & 0.07 & $5,749.46$ & $14,386.50$ & 1.00 & $5,749.46$ & $14,441.58$ & 55.08 & 0.38 \\
\hline & Costruction & 0. & & & & & 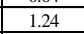 & 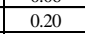 & & 007 & & & & & & & $19,269.80$ & 43,1 & 1.0 & $\begin{array}{ll}19,269.80 \\
\end{array}$ & 94 & 160.74 & 0.37 \\
\hline & Trading & 0. & 0.2 & 0 & 0.15 & & 0.33 & 1.3 & 0.3 & 0.15 & 0.3 & 0.32 & 0.36 & 0.3 & 0.35 & 0.3 & $7,174.15$ & \begin{tabular}{|l|l|}
$56,523.20$ \\
\end{tabular} & 1.00 & $7,174.15$ & $57,037.47$ & 514.27 & 0.91 \\
\hline & Hotels and Restaurants & 0.03 & 0.03 & 0.03 & 0.02 & 0. & 0.04 & 0.06 & 1.09 & 0.03 & 0.07 & 0.05 & 0.06 & 0.07 & 0.06 & 0.06 & 67.13 & $7,715.90$ & 1.00 & 67.13 & $7,774.11$ & 58.21 & 0.75 \\
\hline & $\begin{array}{c}\text { Transport and } \\
\text { Communication }\end{array}$ & 0.15 & & 0.12 & 0.09 & 0 & 21 & 24 & 0.26 & 1.14 & 0.19 & 0.22 & 0.23 & 0.23 & 0.22 & 0.23 & $35,500.44$ & | $67,652.50$ & 1.00 & $35,500.44$ & $67,911.45$ & 258.95 & 0.38 \\
\hline & Financial & 0.04 & 0.03 & 0.03 & 0.02 & 0.05 & 0.05 & 0.07 & 0.10 & 0.04 & 4.15 & 0.06 & 0.05 & 0.07 & 0.06 & 0.08 & 768.10 & $11,748.00$ & 1.00 & 768.10 & $11,820.89$ & 72.89 & 0.62 \\
\hline & $\begin{array}{c}\text { Real estate, rental and } \\
\text { the provision of } \\
\text { services to consumers }\end{array}$ & 0 & & & & & 06 & & & 0.07 & 17 & 1.16 & 0.12 & 0.08 & 0.08 & & $4,807.90$ & $17,718.30$ & 1.00 & $4,807.90$ & $17,810.19$ & 91.89 & 0.52 \\
\hline & \begin{tabular}{|l} 
Public adminstration \\
\end{tabular} & 0.00 & 0.00 & 0.00 & 0.00 & 0.00 & 0.00 & 0.00 & 0.00 & 0.00 & 0.00 & 0.00 & $\frac{1.00}{1.00}$ & 0.00 & 0.00 & 0.00 & $22,055.90$ & $22,088.10$ & 1.00 & $22,055.90$ & $22,088.41$ & 0.31 & \begin{tabular}{|l|l}
0.00 \\
\end{tabular} \\
\hline & $\begin{array}{c}\text { Provision of communal, } \\
\text { social and personal } \\
\end{array}$ & 0.01 & 0.01 & 0.01 & 0.01 & 0.01 & 0.01 & 0.02 & 0.02 & 0.01 & 0.03 & 0.02 & 0.01 & 0.02 & 0.03 & 1.08 & $4,863.80$ & $7,572.30$ & 1.00 & $4,863.80$ & $7,593.07$ & 20.77 & 0.27 \\
\hline
\end{tabular}




\section{Appendix 5}

Calculation of general multiplier based on the Social Accounts Matrix of Kyrgyzstan

Calculation of general multiplier based on the Social Accounts Matrix of Azerbaijan (mln manat)

\begin{tabular}{|c|c|c|c|c|c|c|c|c|c|c|c|c|c|c|c|c|c|c|c|c|c|c|c|}
\hline \multicolumn{24}{|c|}{ Calculation of general multiplier based on the Social Accounts Matrix of Azerbaijan (mln manat) } \\
\hline & & \multicolumn{15}{|c|}{ Activities } & \multicolumn{2}{|c|}{ SAM multiplier model } & \multicolumn{5}{|c|}{ Simulation } \\
\hline & & $\begin{array}{c}\text { Agriculture, } \\
\text { hunting and } \\
\text { forestry }\end{array}$ & $\begin{array}{c}\text { Fishing, } \\
\text { fish- } \\
\text { breeding }\end{array}$ & $\begin{array}{c}\text { Mining } \\
\text { and } \\
\text { quarrying }\end{array}$ & $\begin{array}{c}\text { Manufactu } \\
\text { ring }\end{array}$ & \begin{tabular}{|c} 
production \\
and \\
distributing \\
of electricity, \\
gas and \\
water
\end{tabular} & $\begin{array}{c}\text { Construc } \\
\text { tion }\end{array}$ & $\begin{array}{c}\text { Wholesale } \\
\text { and retail } \\
\text { tradererea } \\
\text { rof } \\
\text { rotor,weh } \\
\text { icles, } \\
\text { personal } \\
\text { and }\end{array}$ & $\begin{array}{c}\text { Serve of } \\
\text { hotels } \\
\text { and } \\
\text { restouran } \\
\text { ts }\end{array}$ & $\mid \begin{array}{c}\text { Transprot } \\
\text { storage } \\
\text { and } \\
\text { communi } \\
\text { cation }\end{array}$ & \begin{tabular}{|} 
Financial \\
intermedi \\
ation
\end{tabular} & \begin{tabular}{|c|} 
Real \\
estate, \\
renting \\
and \\
bussiness \\
activities
\end{tabular} & \begin{tabular}{|c|} 
Public \\
administr \\
ation and \\
defence
\end{tabular} & $\begin{array}{c}\text { Educatio } \\
\mathrm{n}\end{array}$ & $\begin{array}{c}\text { Health } \\
\text { and } \\
\text { social } \\
\text { work }\end{array}$ & \begin{tabular}{|c} 
Other \\
communit \\
y,social \\
and \\
personal \\
service \\
activity
\end{tabular} & $\begin{array}{c}\text { E } \\
\text { exogenous } \\
\text { demand } \\
\text { vector }\end{array}$ & $\begin{array}{c}\mathrm{Z} \text { aggregate } \\
\text { demand vector }\end{array}$ & $\begin{array}{l}\text { Change in } \mathrm{E} \\
\%\end{array}$ & $\begin{array}{c}\text { absolute } \\
\text { change in } \\
\text { the vector } \\
\text { of } \\
\text { exogenous } \\
\text { demand E }\end{array}$ & $\begin{array}{c}\text { Result of } \\
\text { the change } \\
\text { in the } \\
\text { vector of } \\
\text { aggregate } \\
\text { demand }\end{array}$ & $\begin{array}{c}\text { Absolute } \\
\text { result Z }\end{array}$ & $\begin{array}{c}\text { Relative } \\
\text { result Z } \\
\%\end{array}$ \\
\hline \multirow{12}{*}{ O } & $\begin{array}{l}\text { Agriculture, hunting and } \\
\text { forestry }\end{array}$ & 1.35 & 0.09 & 0.12 & 0.11 & 0.10 & 0.12 & 0.10 & 0.12 & 0.10 & 0.13 & 0.13 & 0.13 & 0.13 & 0.08 & 0.14 & 296.04 & $2,554.82$ & & 325.65 & $2,594.69$ & 39.88 & 1.56 \\
\hline & Fishing, fish-breeding & 0.01 & 1.14 & 0.01 & 0.00 & 0.01 & 0.01 & 0.01 & 0.01 & 0.01 & 0.01 & 0.01 & 0.01 & 0.01 & 0.01 & 0.01 & 1.01 & 142.66 & 1.00 & 1.01 & 142.87 & 0.21 & 0.15 \\
\hline & $\begin{array}{l}\text { production and distributing of } \\
\text { electricity, gas and water }\end{array}$ & 0.06 & 0.08 & 0.04 & 0.03 & 1.16 & 0.04 & 0.04 & 0.05 & 0.04 & 0.04 & 0.06 & 0.08 & 0.06 & 0.04 & 0.05 & 25.63 & 725.94 & & 25.63 & 727.80 & 1.86 & 0.26 \\
\hline & Construction & 0.01 & 0.01 & 0.02 & 0.01 & 0.03 & 1.22 & 0.02 & 0.02 & 0.02 & 0.02 & 0.11 & 0.03 & 0.07 & 0.07 & 0.01 & $2,903.02$ & $3,829.50$ & 1.00 & $2,903.02$ & 3.829 .85 & 0.34 & 0.01 \\
\hline & $\begin{array}{c}\text { Wholesale and retail } \\
\text { trade,repair of motor,wehicles, } \\
\text { personal and household } \\
\text { goods }\end{array}$ & 0.08 & 0.07 & 0.10 & 0.04 & 0.09 & 0.11 & 1.18 & 0.09 & 0.12 & 0.15 & 0.12 & 0.09 & 0.10 & 0.08 & 0.12 & 122.49 & $1,876.83$ & 1.00 & 122.49 & $1,879.26$ & 2.43 & 0.13 \\
\hline & $\begin{array}{c}\text { Serve of hotels and } \\
\text { restourants }\end{array}$ & 0.01 & 0.01 & 0.01 & 0.00 & 0.01 & 0.02 & 0.01 & 1.30 & 0.01 & 0.02 & 0.03 & 0.03 & 0.01 & 0.02 & 0.01 & 1.23 & 165.02 & 1.00 & 1.23 & 165.20 & 0.18 & 0.11 \\
\hline & $\begin{array}{l}\text { Transprot, storage and } \\
\text { communication }\end{array}$ & 0.07 & 0.09 & 0.10 & 0.08 & 0.13 & 0.20 & 0.13 & 0.10 & 1.32 & 0.15 & 0.22 & 0.12 & 0.09 & 0.10 & 0.19 & 558.97 & $2,798.78$ & & 558.97 & $2,800.88$ & 2.10 & 0.08 \\
\hline & & 0.02 & 0.02 & 0.02 & 0.01 & 0.02 & 0.02 & 0.02 & 0.02 & 0.03 & 1.10 & 0.02 & 0.03 & 0.02 & 0.02 & 0.02 & 7.95 & 346.40 & 1.00 & 7.95 & 346.86 & 0.46 & 0.13 \\
\hline & $\begin{array}{l}\text { Public administration and } \\
\text { defence }\end{array}$ & 0.03 & 0.03 & 0.04 & 0.01 & 0.03 & 0.03 & 0.03 & 0.04 & 0.03 & 0.04 & 0.05 & 1.06 & 0.04 & 0.03 & 0.04 & 203.00 & 829.10 & & 203.00 & 830.02 & 0.92 & 0.11 \\
\hline & Education & 0.01 & 0.01 & 0.02 & 0.0 & 0.0 & 0.0 & 0.01 & 0.02 & 0.01 & 0.02 & 0.02 & 0.03 & 1.02 & 0.01 & 0.02 & 299.18 & 556.80 & 1.6 & 299.18 & 557.18 & 0.38 & 0.07 \\
\hline & Health and social work & 0.00 & 0.00 & 0.01 & 0.00 & 0.01 & 0.04 & 0.02 & 0.01 & 0.03 & 0.01 & 0.03 & 0.01 & 0.01 & 1.02 & 0.01 & 397.59 & 595.40 & 1.00 & 397.59 & 595.49 & 0.09 & 0.02 \\
\hline & $\begin{array}{l}\text { Other community,social and } \\
\text { personal service activity }\end{array}$ & 0.02 & 0.02 & 0.03 & 0.01 & 0.02 & 0.03 & 0.02 & 0.06 & 0.03 & 0.03 & 0.03 & 0.06 & 0.03 & 0.02 & 1.19 & 38.34 & 491.20 & & 38.34 & 491.82 & 0.62 & 0.13 \\
\hline
\end{tabular}




\section{Appendix 6}

Calculation of general multiplier based on the Social Accounts Matrix of Kazakhstan

Calculation of general multiplier based on the Social Accounts Matrix of Kazakhstan (mln tenge)

\begin{tabular}{|c|c|c|c|c|c|c|c|c|c|c|c|c|c|c|c|c|c|c|c|c|c|c|c|}
\hline & \multicolumn{15}{|c|}{ Activities } & \multicolumn{2}{|c|}{ SAM multiplier model } & \multicolumn{5}{|c|}{ Simulation } \\
\hline & & $\begin{array}{c}\text { Agriculture, } \\
\text { hunting and } \\
\text { forestry }\end{array}$ & \begin{tabular}{|} 
Fishing, fish \\
farming, the \\
provision of \\
services in \\
these fields
\end{tabular} & $\begin{array}{l}\text { Mining } \\
\text { industry }\end{array}$ & \begin{tabular}{|c} 
Manufactu \\
ring \\
industry
\end{tabular} & $\begin{array}{c}\text { Production } \\
\text { and } \\
\text { distribution } \\
\text { of electricity }\end{array}$ & $\begin{array}{c}\text { Costructi } \\
\text { on }\end{array}$ & Trading & $\begin{array}{c}\text { Hotels and } \\
\text { Restaurant } \\
\mathrm{s}\end{array}$ & $\begin{array}{c}\text { Transport } \\
\text { and } \\
\text { Communi } \\
\text { cation }\end{array} \mid$ & $\begin{array}{l}\text { Financial } \\
\text { activities }\end{array}$ & \begin{tabular}{|c|}
$\begin{array}{c}\text { Real } \\
\text { estate, } \\
\text { rental and } \\
\text { the } \\
\text { provision } \\
\text { of services } \\
\text { to } \\
\text { consumers }\end{array}$ \\
\end{tabular} & \begin{tabular}{|c|} 
Public \\
adminstra \\
tion
\end{tabular} & Educatio & $\begin{array}{c}\text { Health } \\
\text { and } \\
\text { social } \\
\text { services }\end{array}$ & $\begin{array}{c}\text { Provision } \\
\text { of } \\
\text { communal, } \\
\text { social and } \\
\text { personal } \\
\text { services }\end{array}$ & $\begin{array}{c}\text { Eexogenous } \\
\text { demand vector }\end{array}$ & $\begin{array}{c}\mathrm{Z} \text { aggregate } \\
\text { demand vector }\end{array}$ & Change in $E \%$ & $\begin{array}{c}\text { absolute change } \\
\text { in the vector of } \\
\text { exogenous } \\
\text { demand E }\end{array}$ & $\begin{array}{l}\text { Result of the } \\
\text { change in the } \\
\text { vector of } \\
\text { aggregate demand }\end{array}$ & Absolute result Z & \begin{tabular}{|l} 
Relative \\
result Z \%
\end{tabular} \\
\hline \multirow{15}{*}{8} & Agriculture, hunting and forestry & 1.34 & 0.09 & 0.08 & 0.09 & 0.08 & 0.09 & 0.10 & 0.09 & 0.10 & 0.08 & 0.09 & 0.45 & 0.13 & 0.11 & 0.10 & \begin{tabular}{|l|}
$234,504,096.05$ \\
\end{tabular} & $2,878,812,299.08$ & 1.10 & $257,954,505.65$ & 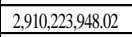 & $31,411,648.94$ & 1.09 \\
\hline & \begin{tabular}{c|} 
Fishing, fish farming, the provision of \\
services in these fields \\
\end{tabular} & 0.07 & 1.21 & 0.13 & 0.13 & 0.06 & 0.05 & 0.07 & 0.05 & 0.05 & 0.04 & 0.04 & 0.06 & 0.05 & 0.06 & 0.05 & $8,462,376,372.60$ & $11,465,996,362.30$ & 1.00 & $8,462,37,3,372.60$ & $11,467,525,789.55$ & $1,529,427.25$ & 0.01 \\
\hline & Mining industry & 0.31 & 0.39 & 1.22 & 0.47 & 0.46 & 0.31 & 0.40 & 0.29 & 0.27 & 0.25 & 0.28 & 0.34 & 0.33 & 0.37 & 0.31 & \begin{tabular}{|l|l}
$4,577,431,120.88$ \\
\end{tabular} & $12,677,030,679.70$ & 1.00 & \begin{tabular}{|l|}
$4,577,431,120.88$ \\
\end{tabular} & $12,684,253,230.04$ & $7,222,550.34$ & 0.06 \\
\hline & Manufacturing industry & 0.04 & 0.06 & 0.03 & 1.14 & 0.04 & 0.05 & 0.06 & 0.05 & 0.04 & 0.04 & 0.04 & 0.05 & 0.06 & 0.06 & 0.08 & $87,786,579.69$ & $1,268,018,822.73$ & 1.00 & $87,786,579.69$ & $1,268,953,293.34$ & $934,470.61$ & 0.07 \\
\hline & Production and distribution of electricity & 0.03 & 0.04 & 0.01 & 0.08 & 1.17 & 0.04 & 0.05 & 0.05 & 0.03 & 0.05 & 0.02 & 0.03 & 0.07 & 0.03 & 0.03 & \begin{tabular}{|l|}
$2,947,006,779.21$ \\
\end{tabular} & $4,172,588,108.12$ & 1.00 & \begin{tabular}{|l|}
$2,947,006,779.21$ \\
\end{tabular} & \begin{tabular}{|l|}
$4,173,392,636.60$ \\
\end{tabular} & $804,528.48$ & 0.02 \\
\hline & Costruction & 0.17 & 0.25 & 0.10 & 0.19 & 0.18 & 1.34 & 0.21 & 0.20 & 0.11 & 0.11 & 0.12 & 0.18 & 0.18 & 0.17 & 0.12 & \begin{tabular}{l|}
$1,950,106,457.16$ \\
\end{tabular} & $6,658,298,201.74$ & 1.00 & \begin{tabular}{|l|}
$1,950,106,457.16$ \\
\end{tabular} & $6,662,244,715.39$ & $3,946,513.65$ & 0.06 \\
\hline & Trading & 0.15 & 0.21 & 0.09 & 0.17 & 0.14 & 0.27 & 1.19 & 0.19 & 0.15 & 0.14 & 0.15 & 0.20 & 0.17 & 0.16 & 0.16 & \begin{tabular}{|l|}
$970,871,109.81$ \\
\end{tabular} & $5,049,543,572.68$ & 1.00 & $970,871,109.81$ & \begin{tabular}{|l|}
$5,052,973,384.11$ \\
\end{tabular} & $3,429,811.43$ & 0.07 \\
\hline & Hotels and Restaurants & 0.03 & 0.05 & 0.02 & 0.04 & 0.03 & 0.06 & 0.04 & 1.07 & 0.02 & 0.04 & 0.04 & 0.05 & 0.04 & 0.06 & 0.02 & $46,871,432.98$ & $\begin{array}{l}992,187,672.27 \\
\end{array}$ & 1.00 & $46,871,432.98$ & \begin{tabular}{|l|}
$992,919,840.12$ \\
\end{tabular} & $732,167.85$ & 0.07 \\
\hline & Transport and Communication & 0.10 & 0.11 & 0.06 & 0.11 & 0.09 & 0.12 & 0.12 & 0.15 & 1.13 & 0.12 & 0.13 & 0.11 & 0.13 & 0.13 & 0.13 & $91,323,449.24$ & $2,483,338,162.00$ & 1.00 & $91,323,449.24$ & 2,485,671,691.87 & $2,333,529.87$ & 0.09 \\
\hline & Financial activities & 0.02 & 0.08 & 0.02 & 0.03 & 0.02 & 0.04 & 0.04 & 0.11 & 0.03 & 1.07 & 0.06 & 0.12 & 0.02 & 0.02 & 0.02 & \begin{tabular}{|l|}
$993,646,039.17$ \\
\end{tabular} & $2,199,400,203.17$ & 1.00 & $993,646,039.17$ & 2,199,959,989.40 & $559,786.23$ & 0.03 \\
\hline & $\begin{array}{c}\text { Real estate, rental and the provision of } \\
\text { services to consumers }\end{array}$ & 0.02 & 0.03 & 0.01 & 0.02 & 0.02 & 0.03 & 0.04 & 0.04 & 0.02 & 0.02 & 1.03 & 0.03 & 0.02 & 0.02 & 0.02 & $136,239,109.36$ & $721,325,024.15$ & 1.00 & $136,239,109.36$ & $721,698,972.98$ & $373,948.84$ & 0.05 \\
\hline & Public adminstration & 0.00 & 0.00 & 0.00 & 0.00 & 0.00 & 0.00 & 0.00 & 0.00 & 0.00 & 0.00 & 0.00 & 1.00 & 0.00 & 0.00 & 0.00 & $\begin{array}{ll}1,369,182,032.29 \\
\end{array}$ & $1,385,779,829.31$ & 1.00 & \begin{tabular}{|l|}
$1,369,182,032.29$ \\
\end{tabular} & $1,385,796,948.71$ & $17,119.40$ & 0.00 \\
\hline & Education & 0.01 & 0.01 & 0.01 & 0.01 & 0.01 & 0.01 & 0.01 & 0.01 & 0.01 & 0.01 & 0.01 & 0.01 & 1.01 & 0.01 & 0.01 & \begin{tabular}{|l|}
$950,586,743.23$ \\
\end{tabular} & $1,175,368,622.00$ & 1.00 & \begin{tabular}{|l|}
$950,586,743.23$ \\
\end{tabular} & \begin{tabular}{|l|}
$1,175,595,841.14$ \\
\end{tabular} & $227,219.14$ & 0.02 \\
\hline & Health and social services & 0.00 & 0.00 & 0.00 & 0.00 & 0.00 & 0.00 & 0.00 & 0.00 & 0.00 & 0.00 & 0.00 & 0.00 & 0.00 & 1.01 & 0.01 & \begin{tabular}{|l|}
$547,397,362.76$ \\
\end{tabular} & $635,708,362.00$ & 1.00 & \begin{tabular}{|l|}
$547,397,362.76$ \\
\end{tabular} & $635,797,029.66$ & $88,667.66$ & 0.01 \\
\hline & $\begin{array}{l}\text { Provision of communal, social and } \\
\text { personal services }\end{array}$ & 0.01 & 0.02 & 0.01 & 0.02 & 0.01 & 0.02 & 0.02 & 0.02 & 0.02 & 0.01 & 0.02 & 0.02 & 0.02 & 0.02 & 1.03 & $241,480,103.58$ & $600,044,166.74$ & 1.00 & $241,480,103.58$ & $600,377,850.02$ & $333,683.28$ & 0.06 \\
\hline
\end{tabular}

